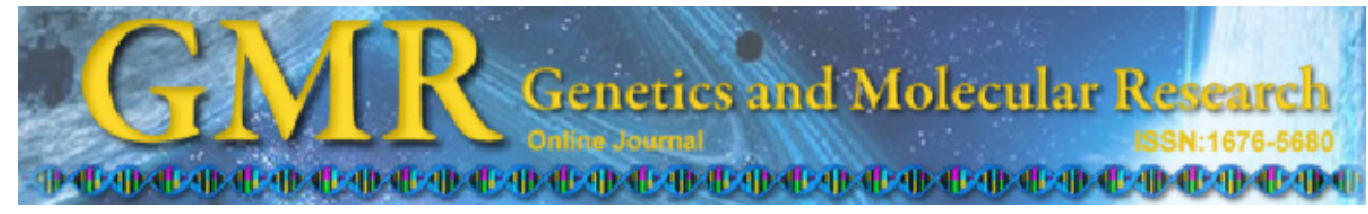

\title{
Sexing single bovine blastomeres using TSPY gene amplification
}

\author{
M.C.A. Carneiro ${ }^{1,2}$, P.L. Takeuchi ${ }^{1}$, A. Araújo ${ }^{1}$, R.B. Lôbo ${ }^{1}$, F.P. Elias ${ }^{1}$, \\ R.A. Vila ${ }^{1}$, C.L. Miranda-Furtado ${ }^{1}$ and E.S. $\operatorname{Ramos}^{1,3}$ \\ ${ }^{1}$ Departamento de Genética, Faculdade de Medicina de Ribeirão Preto, \\ Universidade de São Paulo, Ribeirão Preto, SP, Brasil \\ ${ }^{2}$ Departamento de Biologia, \\ Faculdade de Filosofia, Ciências e Letras de Ribeirão Preto, \\ Universidade de São Paulo, Ribeirão Preto, SP, Brasil \\ ${ }^{3}$ Departamento de Ginecologia e Obstetrícia, \\ Faculdade de Medicina de Ribeirão Preto, \\ Universidade de São Paulo, Ribeirão Preto, SP, Brasil \\ Corresponding author: E.S. Ramos \\ E-mail: esramos@genbov.fmrp.usp.br
}

Genet. Mol. Res. 10 (4): 3937-3941 (2011)

Received April 27, 2011

Accepted August 31, 2011

Published October 25, 2011

DOI http://dx.doi.org/10.4238/2011.October.25.1

ABSTRACT. The testis-specific protein Y-encoded gene (TSPY) is a
Y-specific gene present in variable copy number in many mammalian
species, including cattle. We tested the applicability of the TSPY
gene as a Y-specific marker to predict preimplantation embryo sex
in Nelore (Bos indicus) cattle. Two blastomeres were removed from
each embryo. A total of 36 single blastomeres and the remaining
cells of their 18 matched in vitro conceived embryos were screened
for TSPY amplification by nested-PCR. The results obtained from a
single blastomere and the remaining cells of the same embryo were
concordant in all cases. All blastomeres (16/16) from eight embryos
produced with sexed sperm (specific for production of male embryos)
were TSPY-positive. We conclude that TSPY is a good male-specific
marker, the usefulness of which is probably enhanced by the high copy
number. Other methods that are less time-consuming, such as real-time 
PCR, could be improved with the use of the TSPY gene sequences to generate primers and/or probes. This is the first report to demonstrate the applicability of the TSPY gene for sexing single cells in cattle.

Key words: Sexing; TSPY gene; Bovine; Embryo; Single cell; Cattle

\section{INTRODUCTION}

The identification of bovine embryo gender can be very useful for research involving differential expression of genes between males and females (Chrenek et al., 2001; BermejoAlvarez et al., 2008). Similarly, it can be a valuable tool for assisted reproduction in breeding programs, and may also be commercially explored in the cattle industry.

Many techniques and Y-specific markers have been used for sexing cattle (Lee et al., 2004; Bermejo-Alvarez et al., 2008; Zoheir and Allam, 2010). The application of polymerase chain reaction (PCR) for the analysis of a single cell presents a challenge since limited DNA is available in one single diploid cell, and this can lead to a reduction in amplification efficiency. Lemos et al. (2005) described a study on the TSPY (testis-specific protein Y-encoded) gene as a male-specific marker for cattle sexing in very low DNA concentrations. The TSPY gene is advantageous compared to other markers because it is a Y-specific gene of multiple copies both in human and bovine genomes. After embryo biopsy, the DNA from only one cell is amplified, so, using genes with multiple copies, we could increase the efficiency of the amplification (Bartmann et al., 2004; Lemos et al., 2005).

In the present study, we tested a nested PCR-based protocol, modified from Lemos et al. (2005), in order to sex single cells from bovine preimplantation embryos using a sequence of the TSPY gene (also known as DYS14 in humans).

\section{MATERIAL AND METHODS}

\section{Bovine embryos}

Immature bovine cumulus-oocyte complexes (COCs) were aspirated from 2- to 7-mm follicles in the ovaries of slaughtered cows (Nelore cattle - Bos indicus). The selected oocytes were washed twice in $\mathrm{H} 199+$ medium and twice in B199+ maturation medium. COCs were cultured in $5 \% \mathrm{CO}_{2}$ at $38.7^{\circ} \mathrm{C}$ for $22-24 \mathrm{~h}$ for maturation, in $\mathrm{B} 199+$ covered with mineral oil. The semen straws from Nelore bulls (Bos indicus) were thawed, and the semen was separated on a Percoll (GE) gradient. After the maturation period, the COCs were washed twice in the in vitro fertilization (IVF) medium, and co-incubated with the motile spermatozoa in microdrops of $100 \mu \mathrm{L}(90 \mu \mathrm{L}$ IVF medium $+10 \mu \mathrm{L}$ spermatozoa pellet diluted in IVF medium to a concentration of $2.0 \times 10^{6}$ spermatozoa $/ \mathrm{mL}$ ) covered with mineral oil. The oocytes and spermatozoa were co-incubated for $12-15 \mathrm{~h}$ in $5 \%$ of $\mathrm{CO}_{2}$ at $38.7^{\circ} \mathrm{C}$.

After the fertilization period, the zygotes were washed in IVF medium and three times in CR2+ medium. They were co-cultivated in CR2+ medium for $72 \mathrm{~h}$. After this period, the viable embryos (8-16 cells) were washed and transferred to microdrops with manipulation medium, and, using a micropipette $10 \mu \mathrm{m}$ in diameter coupled to a micromanipulator (Narishigi Co. Ltda., Tokyo, Japan), the embryos were fixed. With the biopsy pipette (35- $\mu \mathrm{m}$ diameter), 
the zona pellucida was broken, and a single blastomere was removed. From each embryo, at least two blastomeres were individually removed. Each single blastomere and the rest of the embryo were individually stored in tubes at $-80^{\circ} \mathrm{C}$.

\section{Molecular analysis}

In the present study, DNA extracted from 18 biopsied embryos (10 obtained by IVF using non-sexed semen, and 8 , by IVF using sexed sorted semen, specific for generating male embryos) were analyzed. We carried out a thermal-shock DNA extraction and $1 \mu \mathrm{L}$ proteinase $\mathrm{K}(25 \mathrm{mg} / \mathrm{mL})$ and $49 \mu \mathrm{L} 0.005 \%$ SDS were added. The tubes were incubated in a water-bath at $55^{\circ} \mathrm{C}$ for $1 \mathrm{~h}$, and incubated in a dry-bath for $30 \mathrm{~min}$ at $99^{\circ} \mathrm{C}$. The tubes were immediately transferred to ice, and the PCR solution was added.

The sequences of the primers, based on sequences reported in other studies (GenBank No. X74028.1, B. taurus TSPY gene) (Jakubiczka et al., 1993), were as follows: forward primer (Ext TSPY S) 5'-CCCGCACCTTCCAAGTTGTG-3', reverse primer (Ext TSPY AS) 5'-TGCTCCTC CACCGTCTTCT-3'. The second set of primers was: 5'-TTGTCACCAGCAGTTGTCACG-3' (Int TSPY S) and 5'-AACCTCCACCTCCTCCACGATG-3' (Int TSPY AS).

The first PCR contained $12.05 \mu \mathrm{L}$ MilliQ water, buffer solution with $1.5 \mathrm{mM} \mathrm{MgCl}{ }_{2}$ Crimson Taq reaction buffer ( $10 \mathrm{mM}$ Tris- $\mathrm{HCl}, 100 \mathrm{mM} \mathrm{KCl}, 0.1 \mathrm{mM}$ EDTA, $1 \mathrm{mM}$ dithiothreitol, $0.5 \%$ Tween 20, 0.5\% NP-40 and 50\% glycerol) (New England BioLabs Inc.), $0.1 \mathrm{mM}$ of each dNTP (Invitrogen), $10 \mathrm{pmol}$ of each external primer (forward and reverse), $0.625 \mathrm{U}$ Crimson Taq DNA polymerase and $8 \mu \mathrm{L}$ lysis solution containing all the extracted DNA. The second PCR consisted of $22 \mu \mathrm{L}$ MilliQ water, buffer solution with $1.5 \mathrm{mM} \mathrm{MgCl}{ }_{2}$ Crimson Taq reaction buffer (New England BioLabs Inc.), $0.1 \mathrm{mM}$ of each dNTP, 10 pmol of each internal primer (forward and reverse), $0.625 \mathrm{U}$ Crimson Taq DNA polymerase and $3 \mu \mathrm{L}$ first PCR product.

The DNA sequence was amplified in a T Gradient (Biometra) thermocycler by an initial denaturation step at $95^{\circ} \mathrm{C}$ for $1 \mathrm{~min}$, followed by 40 cycles of denaturation at $95^{\circ} \mathrm{C}$ for $45 \mathrm{~s}$, annealing at $60^{\circ}$ and $64^{\circ} \mathrm{C}$ (first and second PCR, respectively) for $45 \mathrm{~s}$ and elongation at $68^{\circ} \mathrm{C}$ for $45 \mathrm{~s}$. An additional extension time of $10 \mathrm{~min}$ at $10^{\circ} \mathrm{C}$ was added at the end of the final cycle. The amplification products ( $328 \mathrm{bp}$ for the first set of primers, and $153 \mathrm{bp}$ for the second) were analyzed by electrophoresis in $8 \%$ polyacrylamide gels stained with $2 \%$ silver nitrate. As a DNA positive control, we used a bovine $\beta$-actin gene sequence previously described (Rios et al., 2007).

We compared the results of each single blastomere (in a total of two blastomeres from each embryo) with the data obtained from the other blastomere and the remaining cells of the same embryo. Each reaction contained DNA extracted from testis (male control) and cow blood samples (female control) as controls.

\section{RESULTS}

The results are illustrated in Figure 1 and summarized in Table 1. For all embryos, the results of the three samples (two blastomeres and the remaining cells of the embryo) matched. All sexed semen-derived embryos showed results compatible with male embryos, as expected. 


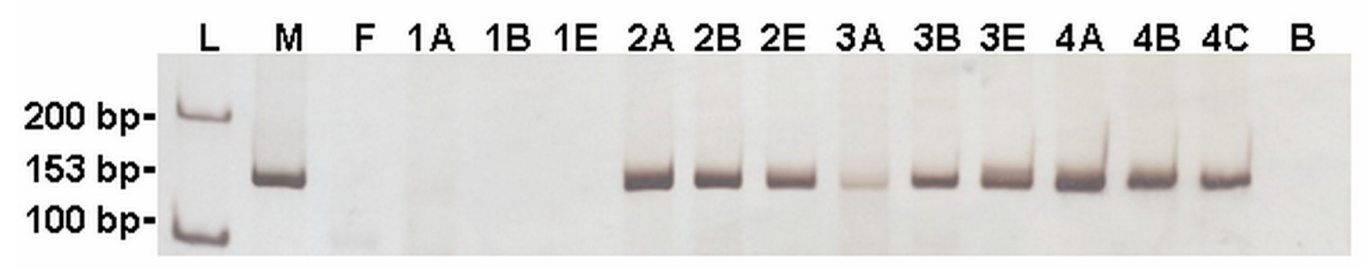

Figure 1. Results of polyacrylamide gel electrophoresis with silver nitrate staining. When the band (153 bp) was present, the result was considered TSPY-positive. (L) molecular marker (100 bp); (M) testicular tissue or male control; (F) cow's blood or female control; (1-4) embryos numbered according to Table 1; (A and B) single blastomeres; (E) remaining cells of the matched embryo; (B) negative control without DNA.

\begin{tabular}{|c|c|c|c|c|}
\hline \multirow[t]{2}{*}{ Embryos } & Blastomere 1 & Blastomere 2 & Remaining cells & Gender \\
\hline & $T S P Y$ & $T S P Y$ & $T S P Y$ & \\
\hline \multicolumn{5}{|c|}{ Non-sexed semen } \\
\hline 1 & - & - & - & Female \\
\hline 2 & + & + & + & Male \\
\hline 3 & + & + & + & Male \\
\hline 4 & + & + & + & Male \\
\hline 5 & + & + & + & Male \\
\hline 6 & - & - & - & Female \\
\hline 7 & + & + & + & Male \\
\hline 8 & + & + & + & Male \\
\hline 9 & - & - & - & Female \\
\hline 10 & + & + & + & Male \\
\hline \multicolumn{5}{|c|}{ Sexed semen } \\
\hline 11 & + & + & + & Male \\
\hline 12 & + & + & + & Male \\
\hline 13 & + & + & + & Male \\
\hline 14 & + & + & + & Male \\
\hline 15 & + & + & + & Male \\
\hline 16 & + & + & + & Male \\
\hline 17 & + & + & + & Male \\
\hline 18 & + & + & + & Male \\
\hline
\end{tabular}

\section{DISCUSSION}

The genomic TSPY organization of the bovine and human genes is highly conserved (Vogel et al., 1997). In Bos taurus, most breeds have a similar average TSPY copy number (94 copies) (Hamilton et al., 2009). In a previous study, we reported that PCR using primers derived from a TSPY sequence allows the detection of the Y chromosome in male animals (Nelore cattle) even at low DNA concentrations. These preliminary results showed the potential of this gene as a male-specific marker (Lemos et al., 2005).

In the present study, we were able to identify embryo sex in a quick and specific way, using a single biopsied blastomere and a nested PCR with the TSPY gene.

Despite the fact that the accuracy of the sexed sorted sperm process is about $90 \%$ (Seidel, 2003), we carried out experiments with embryos produced with this type of sperm in an attempt to produce more male embryos. In fact, we obtained $100 \%$ presumptive male embryos in this small sample set. The sex determination of bovine embryos using TSPY 
sequences may be useful in future efficiency studies of sorting sperm.

When we studied embryos conceived with unsorted semen, we chose the morphologically superior embryos, with higher number of cells, which could explain the disproportion of males and females (7:3, respectively). This was observed in the embryos conceived by non-sexed semen, probably due to differences in the in vitro development between males and females bovine embryos.

The results of $100 \%(36 / 36)$ of blastomeres (single cells) matched the data from the remaining cells of the same embryo. The mechanism that explains the accuracy of our results is that the TSPY is multicopied in the male bovine genome and differs from other Y-specific genes such as the $S R Y$ gene utilized in some studies, which has only one copy.

Due to the importance of preimplantation sexing and genetic diagnosis, it is necessary to have highly sensitive and specific techniques. On the other hand, they also need to be inexpensive and less time-consuming. This protocol could be used as a screening test of embryo sex in expression experiments using pools of embryos, and to test accuracy of the sexed sorted sperm process or the quality of sexed sorted sperm lots. Another technical option could be real-time PCR, but the equipment required is much more expensive than the one used for a simple nested PCR. The latter can be found in services with low complexity and financial resources. It is a very important advantage, for example, in developing countries.

The present study is the first report in the literature using the TSPY gene for bovine embryo sexing of a single cell.

\section{ACKNOWLEDGMENTS}

Research supported by FAPESP (Processes \#2005/00616-5 and \#2009/08313-2), CNPq (Process \#408856/2006-8), ANCP, and FAEPA. We thank the staff of the Epigenetics and Reproduction Group, especially Mrs. Marli A.V. Galerani.

\section{REFERENCES}

Bartmann AK, Ramos ES, Caetano LC, Rios AF, et al. (2004). TSPY detection in blood, buccal, and urine cells of patients with 45,X karyotype. Am. J. Med. Genet. A. 130A: 320-321.

Bermejo-Alvarez P, Rizos D, Rath D, Lonergan P, et al. (2008). Epigenetic differences between male and female bovine blastocysts produced in vitro. Physiol. Genomics 32: 264-272.

Chrenek P, Boulanger L, Heyman Y, Uhrin P, et al. (2001). Sexing and multiple genotype analysis from a single cell of bovine embryo. Theriogenology 55: 1071-1081.

Hamilton CK, Favetta LA, Di Meo GP, Floriot S, et al. (2009). Copy number variation of testis-specific protein, Y-encoded (TSPY) in 14 different breeds of cattle (Bos taurus). Sex Dev. 3: 205-213.

Jakubiczka S, Schnieders F and Schmidtke J (1993). A bovine homologue of the human TSPY gene. Genomics 17: 732735.

Lee JH, Park JH, Lee SH, Park CS, et al. (2004). Sexing using single blastomere derived from IVF bovine embryos by fluorescence in situ hybridization (FISH). Theriogenology 62: 1452-1458.

Lemos DC, Rios AFL, Lobo RB and Vila RA (2005). Use of the TSPY gene for sexing cattle. Genet. Mol. Biol. 28: 117 119.

Rios AFL, Lemos DC, Fernandes MB and Andrea MV (2007). Expression of the CTCF gene in bovine oocytes and preimplantation embryos. Genet. Mol. Biol. 30: 1202-1205.

Seidel GE Jr (2003). Economics of selecting for sex: the most important genetic trait. Theriogenology 59: 585-598.

Vogel T, Dechend F, Manz E, Jung C, et al. (1997). Organization and expression of bovine TSPY. Mamm. Genome 8: 491-496.

Zoheir KM and Allam AA (2010). A rapid method for sexing the bovine embryo. Anim. Reprod. Sci. 119: 92-96. 